\title{
Purification and characterization of amylase from local isolate
} Pseudomonas sp.SPH4

\section{تنقية وتوصيف انزيم الاميليز من العزلة المحلية لبكتيريا الـ Pseudomonas sp. SPH4}

Ghazi M. Aziz

Hala M. Ali

University of Baghdad/College of Science/Dept. of Biotechnology

هالة مشعل علي

قسم التقنيات الاحيائية / كلية العلوم / جامعة بغداد

غازي منعم عزيز

\section{Abstract}

The amylase produced from local isolate Pseudomonas sp. SPH4 was purified by precipitation with $30 \%$ saturation ammonium sulphate, followed by ionexchange chromotography using DEAE-cellulose column, and Gel filtration using Sephacryl S-300 column.The two iso-enzymes $(a, b)$ were purified to $(2.83$, 3.47) times in the last step with an enzymes yields of $(32.36,76.34) \%$ respectively. Enzyme characterization of the two iso-enzymes indicated that the optimum $\mathbf{p H}$ for the two iso-enzymes a and b were $(7,7.5)$ respectively, while the optimum pH for the iso-enzymes stability were $(6.5,7)$ respectively. The maximum activity for iso-enzymes (a, b) appeared at $4^{\circ} \mathrm{C}$ and stable for $15 \mathrm{~min}$ at $30-50^{\circ} \mathrm{C}$ and lost approximately $50 \%$ of it's activity at rang above $75^{\circ} \mathrm{C}$. Enzyme characterization results showed that the chlorides of silver and mercury had inhibitory effect on enzyme activity, the remaining enzyme activity for the iso-enzymes (a, b) were (46.66, 36.36)\% for silver ions and $(41.33,33.63) \%$ for mercury ions at $5 \mathrm{mM}$ respectively, and $(28,28.18) \%$ for silver ions and $(25.33,19.09) \%$ for mercury ions at $10 \mathrm{mM}$ respectively. The iso-enzymes a and $b$ were affected by chelating agent ethylene diamine tetra acetic acid (EDTA) at concentration $2 \mathrm{mM}$ the remaining activity $(45.33,43.63) \%$ respectively, and $5 \mathrm{mM}$ the remaining activity $(28,28.18) \%$ respectivily, and these iso-enzymes $(a, b)$ refered to metalloenzymes. The iso-enzymes $(a, b)$ were kept their activity when treated by reducing agent (2-mercaptoethanol) at $2 \mathrm{mM}$ the remaining activity $(92,92.72) \%$ respectively, and $5 \mathrm{mM}$ the remaining activity $(85.3,89.09) \%$ respectivily. The iso-enzymes (a, b) were kept their activity when treated by phenyl methyl sulphonyl fluoride (PMSF) at concentration $1 \mathrm{mM}$ the remaining activity (93.33, 90.90)\% respectivily, and $5 \mathrm{mM}$ the remaining activity (90.66, 87.27)\% respectivily, and these indicated that these iso-enzymes didnot referred to serine amylases group.

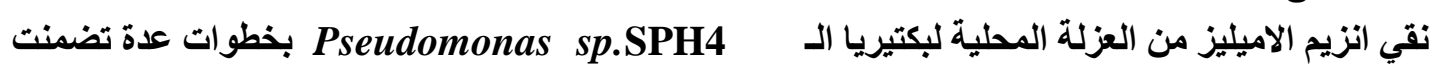

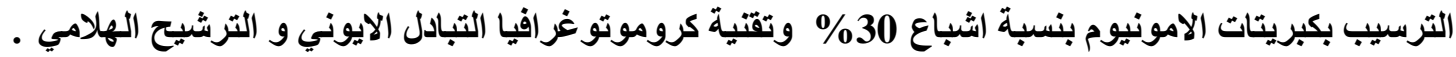

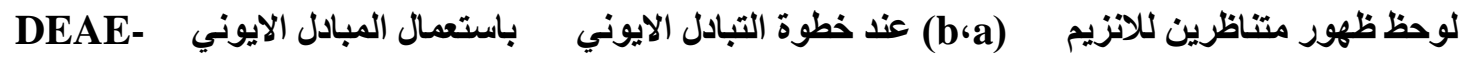
cellulose

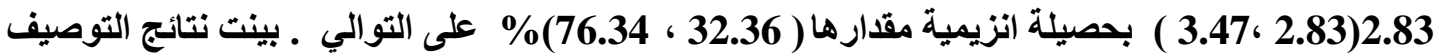

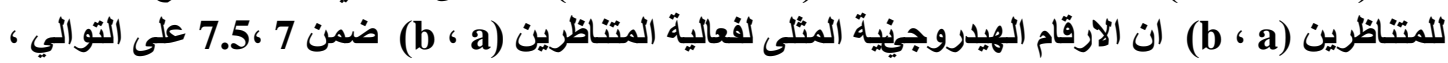

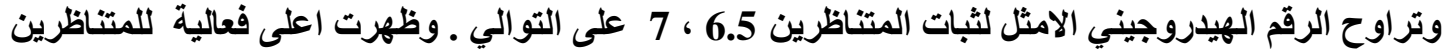

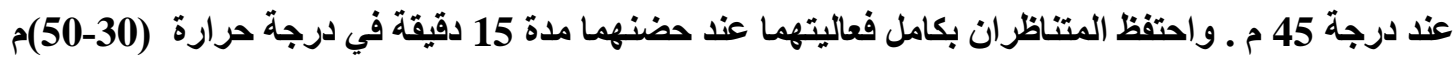

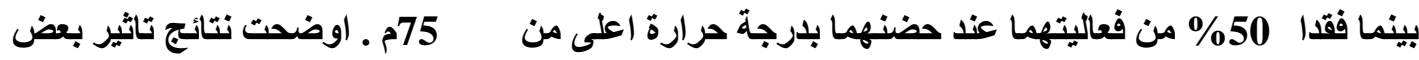


المركبات في فعالية الانزيم ان لكل من كلوريد الزئبق والفضة تاثيرا تثبيطيا واضحا في فعالية المتناظرين و لم

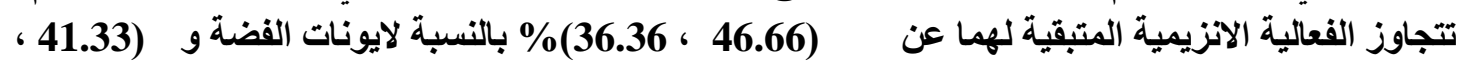

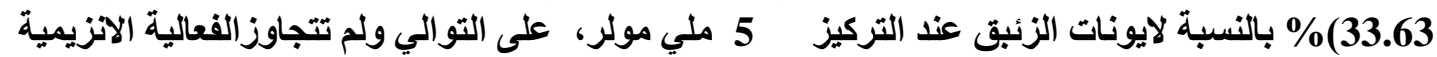

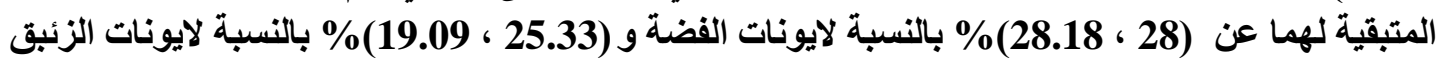

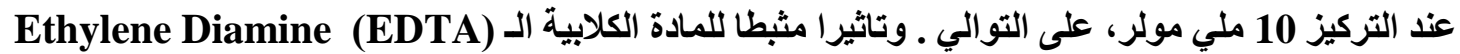
Tetra Acetic acid

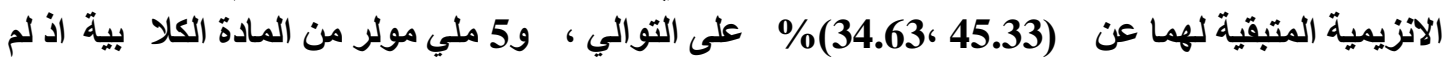

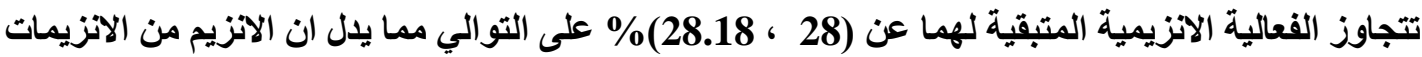

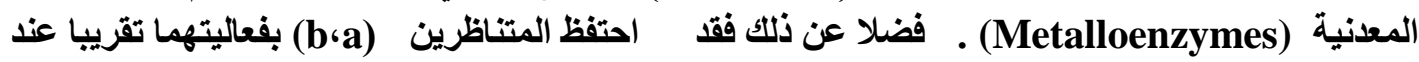

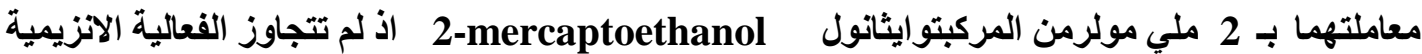

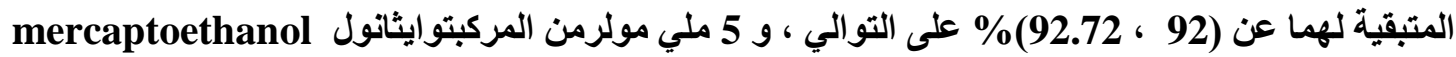

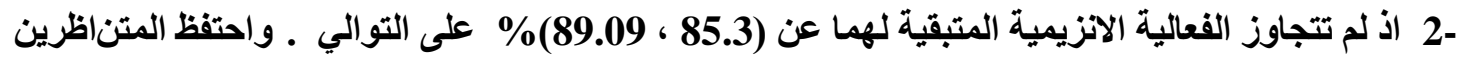

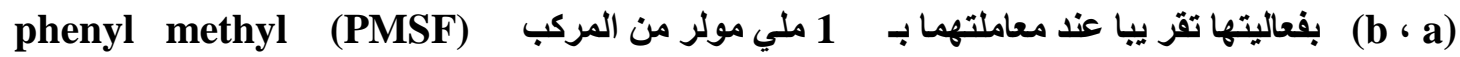
sulphonyl flouride ، و5 ملي مولر من المركب phenyl methyl sulphonyl flouride (PMSF) اذلم لم تتجاوز الفعالية

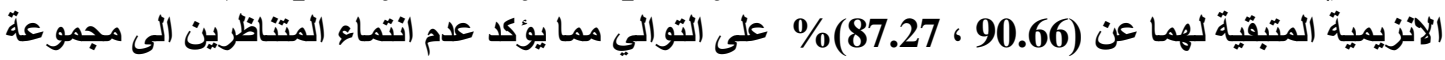

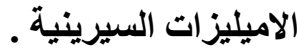

\section{Introduction}

Amylases are enzymes which hydrolyze the starch molecules into simple polymers composed of glucose units. Amylases are ubiquitous in distribution, with plants, bacteria and fungi being the predominat sources [1]. Amylases hydrolysis the $\alpha-1,4$ glycosidic linkage of starch in a random endo-amylolytic fashion [2]. Amylases find potential application in a number of industrial processes such as in the food, fermentation, textiles and papers industries. Amylases were isolated from numerious bacteria such as Pseudomonas amylodermosa, which has the highest producing ability, Bacillus amyloliquefaciens, B.stearothermophilus, B.licheniformis, B.subtilis, B.flavothermus, Escherichia coli, Lactobacillus amylovorus and Flavobacterium sp. [3]. Alpha-amylase was purified from Thermus sp. till homogenity,the fold of purification was 360 [4].While in Bacillus sp. alpha-amylase was purified by concentration of crude extract first by using ultrafiltration, then passed on ionexchange (Hi trap column), then pass on gel filtration column (Sephacryl S-300) folds of purification were 209 fold and the enzyme recovery was 13.2\% [5]. Amylase enzyme was purified from Pseudomonas stutzeri by MO-precipitation (20-40)\%, ionexchange chromatography with (DEAE-Toyopeal) 650S, the purity of each fraction containing enzyme activity was checked by sodium dodocyl sulphate-polyacrylamide gel electophoresis and the fraction giving a single protein band were pooled and used for further studies [6]. The effect of some compounds in enzyme activity was monitered that different metal ions had different effect on the activity of amylase. Many studies showed that calcium ions have the large effect on amylase activity and stability and made the amylase more stable in high temperature [7]. All studies showed that the metal ions such as silver, mercury, aluminum, and copper have inhibitory effect on amylase activity [3]. The effect of different chemical materials in amylase activity such as PMSF (Phenyl Methyl Sulphonyl Fluoride). The activity of alpha-amylase produced from Bacillus $s p$. didn't affected by $10 \mathrm{mM}$ of this 
compound [5]. Studies the effect of chelating EDTA (Ethylene Diamine Tetra Acetic Acid) on amylase produced from Bacillus sp.K-12 it has inhibitor effect on amylase activity [8]. The activity of amylase produced from Bacillus stearothermophilus didn't affect by using the reducing agent (ß-mercaptoethanol) [9]. This study aimed to purification and characterization of amylase from local isolate Pseudomonas sp.SPH4.

\section{Materials and methods}

\section{Isolation of amylase enzyme}

Amylase enzyme was extracted from local isolate Pseudomonas sp. SPH4 identified in previous study [10]. After inoculating the isolate in the production media composed of the starch as carbon source $1 \%$, ammonium sulphate as nitrogen source $1 \%$, calcium chloride $0.05 \%$, sodium chloride $0.05 \%$, magnesium phosphate $0.05 \%$, and di-hydrogen sodium phosphate $0.16 \%$ and the $\mathrm{pH}$ was adjusted at 8 . The production media was inoculated with $1 \times 10^{8}$ cell/ml, after 24 hours of incubation in $37^{\circ} \mathrm{C}$ shaker incubator at $150 \mathrm{rpm} / \mathrm{min}$, cultures was centrifuged at $6000 \mathrm{rpm}$ for $20 \mathrm{~min}$. Enzyme activity and protein concentration were then estimated in the crude filtrates. Activity of amylase was estimated according to reducing sugar liberated after hydrolysis of starch by the enzyme $[11,12]$. Protein concentration was estimated according to the procedure of [13] . The unit of enzyme activity was defined as the amount of enzyme that liberates $1 \mathrm{mM}$ of reducing sugars (maltose) in one minute at reaction conditions[14].

\section{Purification of amylase}

\section{Precipitation by ammonium sulphate}

The supernatant (crude extract) was fractionated with ammonium sulphate at $(20,30$, $40,50,60,70,80) \%$ saturation then the precipitate obtained by centrifugation at $10000 \mathrm{rpm}$ for $30 \mathrm{~min}$ was suspended in $5 \mathrm{ml}$ of $0.05 \mathrm{M}$ phosphate buffer $\mathrm{pH} 7$ and the enzyme activity and protein concentration were measured.

\section{Ion exchange chromatography}

DEAE-cellulose ionic exchange was prepared according to [15]. The sample obtained after ammonium sulphate precipitation with saturation ratio $30 \%$ after dialysis the crude enzyme in distilled water for $24 \mathrm{hr}$. then the concentrated enzyme solution was applied to a DEAE-cellulose column $(2 \times 18 \mathrm{~cm})$ previously equilibrated with $50 \mathrm{mM}$ phosphate buffer $\mathrm{pH}$. The column was washed with the same buffer and eluted with a linear salt gradient with the same buffer containing $(0.1-1) \mathrm{M} \mathrm{NaCl}$. The fractions were collected in test tubes at flow rate $30 \mathrm{ml} /$ hour. Protein concentration in each fraction was monitored spectrophotometrically at $280 \mathrm{~nm}$. Fractions of the protein peaks were assayed for amylase activity. Fractions containing enzymatic activity were collected and concentrated for further experiment.

\section{Gel filtration chromatography}

The gel Sephacryl S-300 was prepared according to the instruction of the manufacturer (Pharmacia Fine Chemical). The fractions collected from DEAEcellulose column chromatography were applied to a Sephacryl S-300column $(2.5 \times 37)$ $\mathrm{cm}$ previously equilibrated with $0.2 \mathrm{M}$ phosphate buffer $\mathrm{pH}$. Elution was performed with the same buffer. The fractions were collected in test tubes at flow rate 30 
$\mathrm{ml} /$ hour. Protein concentration in each fraction was monitored spectrophotometrically at $280 \mathrm{~nm}$. Fractions containing enzymatic activity were collected and stored in refrigerator for further characterization.

\section{Enzyme characterization}

\section{Effect of pH on amylase activity}

Buffer solutions of different $\mathrm{pHs}$ (4-10) were prepared $0.1 \mathrm{ml}$. of partially purified amylase was added to $0.9 \mathrm{ml}$. of a buffer solution containing $1 \%$ soluble starch as a substrate, enzyme activity was assayed for each $\mathrm{pH}$.

\section{Effect of pH on amylase stability}

Equal volumes of partially purified enzyme and buffer solution with $\mathrm{pH}$ ranging from $(4,10)$ were incubated in a water bath at $35^{\circ} \mathrm{C}$ for $30 \mathrm{~min}$. Then transferred immediately into an ice bath. The enzymatic activity for each $\mathrm{pH}$ was measured.

\section{Effect of temperature on amylase activity}

Amylase activity was assayed at various temperature $(25,30,35,40,45,50,55,60$, $65,70,75,80)^{\circ} \mathrm{C}$. Activity of amylase was plotted against the temperatures to determine the optimal temperature for amylase activity.

\section{Effect of temperature on amylase stability}

Equal volumes of partially purified enzyme were incubated for $15 \mathrm{~min}$ at different temperature $(25,30,35,40,45,50,55,60,65,70,75,80)^{\circ} \mathrm{C}$ then immediately transferred into an ice bath. Enzymatic activity was measured and the remaining activity (\%) was plotted against the temperature.

\section{Effect of PMSF on enzyme activity}

Equal volumes of partially purified enzyme were mixed with $(1,5) \mathrm{mM}$ of PMSF (dissolved in methanol) and incubated in water bath at $35^{\circ} \mathrm{C}$ for $15 \mathrm{~min}$ then immediately transferred into an ice bath. The remaining activities (\%) were estimated.

\section{Effect of metal ions, reducing and chelating agents on enzyme activity}

Equal volumes of partially purified enzyme were mixed with $(5,10) \mathrm{mM}$ of different metal salts $(\mathrm{CuSO} 4, \mathrm{AgCl}, \mathrm{HgCl} 2, \mathrm{CaCl} 2)$ and incubated in water bath at $35^{\circ} \mathrm{C}$ for 15 min.These metal ions were prepared by dissolving these metal salts in phosphate buffer pH7.

Equal volumes of partially purified enzyme were mixed with $(2,5) \mathrm{mM}$ of chelating agent Ethylene Diamine Tetra Acetic acid (EDTA) and reducing agent (Bmercaptoethanol) and incubated in water bath at $35 \mathrm{C}^{\circ}$ for $15 \mathrm{~min}$. These compounds were prepared by dissolving these compounds in phosphate buffer $\mathrm{pH} 7$. The remaining activity $(\%)$ was estimated.

\section{Results and discussion}

\section{Extraction and purification of enzyme}

The crude amylase produced by the locally isolate Pseudomonas sp.SPH4 under the optimum conditions had specific activity $31.7 \mathrm{U} / \mathrm{mg}$ protein.

\section{Precipitation of enzyme by ammonium sulphate}

In order to concentrate the crude extract of amylase and remove a much of water and some protein molecules as possible, ammonium sulphate were used at $(20,30,40,50$, $60,70,80) \%$ saturation, the saturation ratio $30 \%$ was used. It achieved specific activity $58.33 \mathrm{U} / \mathrm{mg}$ protein, 1.84 purification fold with $88.33 \%$ yield. Protein 
precipitation by ammonium sulphate depends on the salting out phenomenon. Since ammonium sulphate has the ability to neutralize charges at the surface of the protein and to disrupt the water layer surrounding the protein, it will eventually cause a decrease in the solubility of the protein which, in turn will lead to the precipitation of the protein by the effect of salt $[16,17]$. Ammonium sulphate are widely used because of its availability, high solubility, low cost and it stabilizes the proteins [18].

\section{Ion-Exchange chromatography}

Purification of amylase was done by ion-exchange chromatography by (DEAEcellulose). Results in Table (1) showed amylase purified by using anion-exchange column chromatography using DEAE-cellulose. Figure (1) showed the wash and elution of DEAE-column. The wash step of DEAE-column contained two protein peaks without amylase activity, while the eluted fractions of DEAE-cellulose revealed three protein peaks one peak for protein and two peaks had amylase activity. This results indicates that Pseudomonas sp. SPH4 amylase have negative charge. Appearance of two peaks for amylase activity they reffered to the appearance of isoenzymes of amylase. The fractions which had amylase activity were collected together giving specific activity of $66.66 \mathrm{U} / \mathrm{mg}$ protein with 2.1 fold of purification and $37.85 \%$ yield for the first peak (iso-enzyme a) (the fractions 91-100) and 78.94 $\mathrm{U} / \mathrm{mg}$ protein with 2.94 fold of purification and $80.44 \%$ yield for the second peak (iso-enzyme b) (the fractions 101-112). These result are similar to those found by [19] who purified alpha-amylase from Bacillus stearothermophilus by DEAE-cellulose chromatography and which revealed two peaks of amylase activity in the elution step each peak have alpha-amylase activity.

\section{Gel filtration chromatography}

The fractions of two peaks containing amylase activity from DEAE-cellulose column chromatography were applied to a Sephacryl S-300 column. Figure $(2,3)$ showed that there are two peaks, with specific activity $90 \mathrm{U} / \mathrm{mg}$ proteins, fold of purification 2.83 and yield $32.36 \%$, for first peak and with specific activity $110 \mathrm{U} / \mathrm{mg}$ proteins, fold of purification 3.47 and yield $76.34 \%$ for second peak. Amylase produced from Bacillus $s p$. was purified by Hi prep Sephacryl S- 200, a fold of purification was 709 with a yield1 $3.2 \%$ (5). 
Table (1): Purification steps of amylase (iso-enzyme a and b) produced by Pseudomonas sp.SPH4

\begin{tabular}{|c|c|c|c|c|c|c|c|}
\hline Steps of purification & $\begin{array}{c}\text { Volume } \\
(\mathrm{ml})\end{array}$ & $\begin{array}{c}\text { Activity } \\
\text { (U/ml) }\end{array}$ & $\begin{array}{l}\text { Protein } \\
\text { conc. } \\
(\mathrm{mg} / \mathrm{ml})\end{array}$ & $\begin{array}{l}\text { Specific } \\
\text { activity } \\
(\mathrm{U} / \mathrm{mg})\end{array}$ & $\begin{array}{l}\text { Total } \\
\text { activity } \\
\text { (U) }\end{array}$ & $\begin{array}{l}\text { Fold of } \\
\text { purifica } \\
\text { tion }\end{array}$ & $\begin{array}{c}\text { Yield } \\
(\%)\end{array}$ \\
\hline Crude extract & 25 & 6.34 & 0.2 & 31.7 & 158.5 & 1 & 100 \\
\hline $\begin{array}{l}\text { Precipitation by } \\
\text { saturation } \\
\text { ammonium } \\
\text { sulphate } \\
\mathbf{3 0 \%}\end{array}$ & 8 & 17.5 & 0.3 & 58.33 & 140 & 1.84 & 88.33 \\
\hline $\begin{array}{c}\text { Ion exchange } \\
\text { chromatography by } \\
\text { DEAE-cellulose } \\
\text { (Iso-enzyme a) }\end{array}$ & 15 & 4 & 0.06 & 66.67 & 60 & 2.1 & 37.85 \\
\hline & 17 & 7.5 & 0.095 & 78.95 & 127.5 & 2.49 & 80.44 \\
\hline $\begin{array}{c}\text { chromatography by } \\
\text { Sephacryl S-300 } \\
\text { (Iso-enzyme a) }\end{array}$ & 19 & 2.7 & 0.03 & 90 & 51.3 & 2.84 & 32.37 \\
\hline (Iso-enzyme b) & 22 & 5.5 & 0.05 & 110 & 121 & 3.47 & 76.34 \\
\hline
\end{tabular}

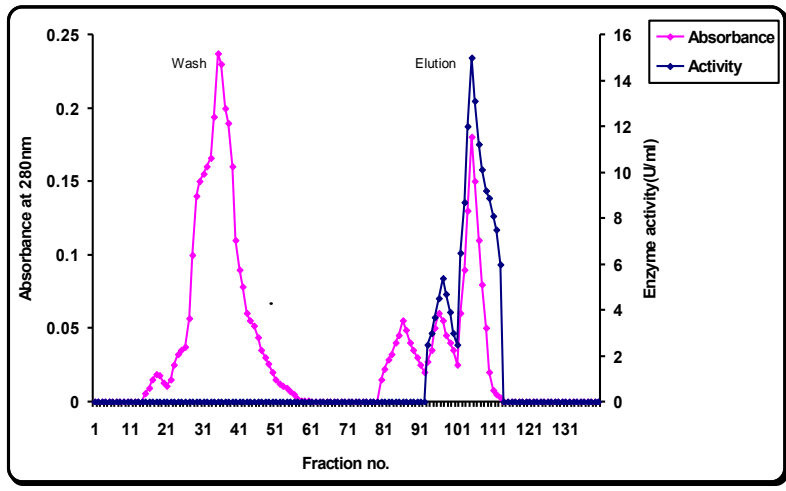

Figure (1): Purification of amylase from local isolate Pseudomonas sp.SPH4 by DEAE-cellulose ionexchange chromatography column $(2 \times 18 \mathrm{~cm})$ equilibrated with $0.05 \mathrm{M}$ phosphate buffer $\mathrm{pH} 7$, enzyme was eluted with linear salt gradient 0.1-1 M Nacl, flow rate $30 \mathrm{ml} / \mathrm{hour}$

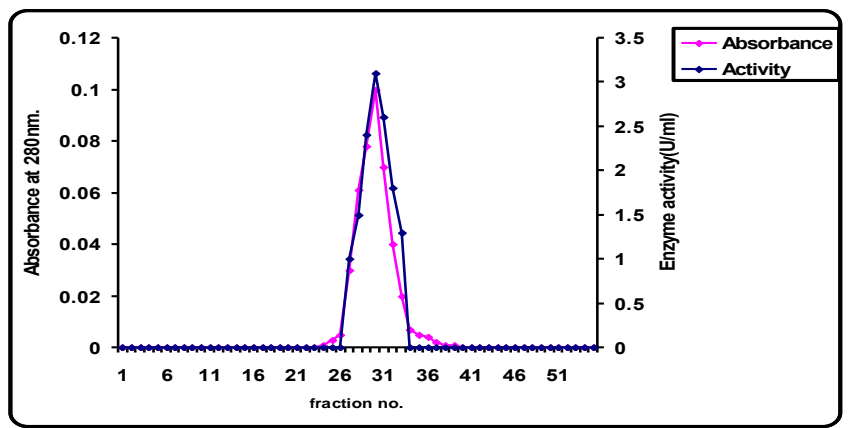

Figure(2): Gel filtration chromatography of amylase (iso-enzyme a) from local isolate Pseudomonas $s p . S P H 4$ by Sephadex S-300 column $(2.5 \times 37 \mathrm{~cm})$ equilibrated with $0.2 \mathrm{M}$ phosphate buffer pH 7,flow rate $30 \mathrm{ml} /$ hour 


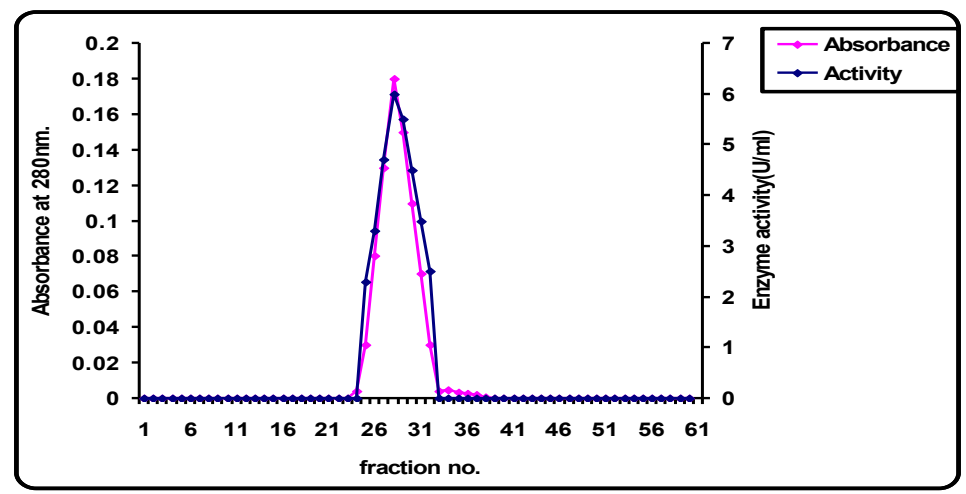

Figure (3): Gel filtration chromatography of amylase (iso-enzyme b) from local isolate Pseudomonas sp.SPH4 by Sephadex S-300 column $(2.5 \times 37 \mathrm{~cm})$ equilibrated with $0.2 \mathrm{M}$ phosphate buffer $\mathrm{pH}$ 7, flow rate $30 \mathrm{ml} / \mathrm{hour}$

Enzyme characterization

\section{Optimum pH of amylase activity}

Figure (4) showed the effect of $\mathrm{pH}$ on the activity of partially purified amylase from Pseudomonas sp.SPH4 was studied in $\mathrm{pH}$ rang from 4-10. Results showed that the maximum activity of amylase (iso-enzyme a,b) was at $\mathrm{pH}(7,7.5)$, respectivily the activity was $6.5 \mathrm{U} / \mathrm{ml}$ for iso-enzyme (a) and $9.5 \mathrm{U} / \mathrm{ml}$ for iso-enzyme (b). $\mathrm{pH}$ has effect on the ionic state of enzyme by effecting on the amino acid chains necessary for tertiary structure of enzyme and hence its activity may varies. Higher or lower $\mathrm{pH}$ from the optimum will lead to denature the enzyme and losing it's activity $[15,16$, 20]. The optimum $\mathrm{pH}$ for isoamylase activity from the yeast Lipomyces kononenkoae was 5.6 [21].

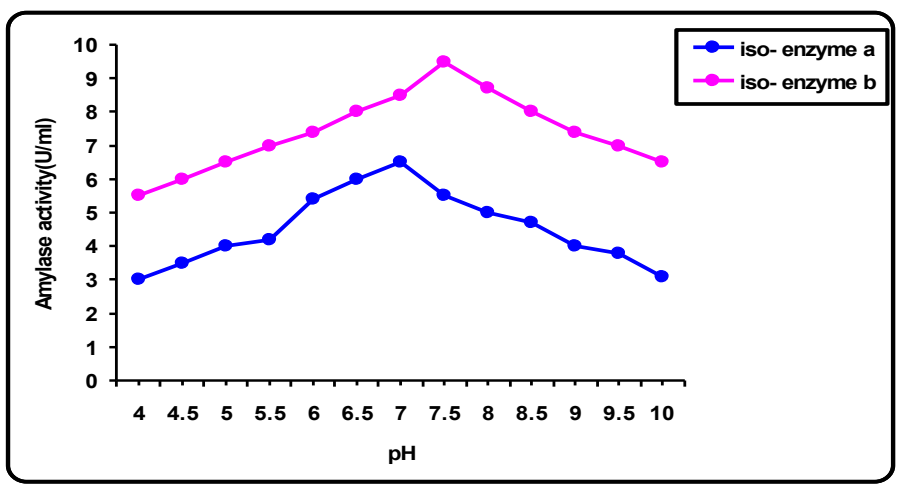

Figure (4): Effect of pH on purified of Pseudomonas sp.SPH4 amylase (iso-enzymes)

\section{Effect of pH on amylase stability}

In order to determine the optimum $\mathrm{pH}$ for amylase stability, the enzyme was incubated in buffer solution with $\mathrm{pH}$ range (4-10) at $35^{\circ} \mathrm{C}$ for $15 \mathrm{~min}$. Results indicated in Figure (5) showed that amylase (iso-enzyme a and b) high stability at $\mathrm{pH}$ range between (6.5-7.5) the activity of amylase (iso-enzyme a) was $7.5 \mathrm{U} / \mathrm{ml}$ and the activity of (iso-enzyme b) was $10.1 \mathrm{U} / \mathrm{ml}$, in which it kept more than $90 \%$ of it's total activity. The effect of $\mathrm{pH}$ on the enzyme stability could be explained in the formation of ionic form of enzyme or the active sites, irreversible inactivation. The stability of the enzyme depends on many factors such as temperature, ionic strength, chemical nature of buffer, concentration of various preservatives, concentration of metal ions, substrate and enzyme concentration [16].Whitaker indicated that most amylase from 
Pseudomonas sp. have optimum $\mathrm{pH}$ (3.5-5.5) [15]. The amylase produced from Bacillus sp. have a wide range of $\mathrm{pH}$ between (6-11) [5].

\section{Effect of temperature on amylase activity}

The results in Figure (6) indicated that the activity of amylase (iso-enzyme a and b) reaches the maximum $(7.4,10.2) \mathrm{U} / \mathrm{ml}$ respectively at $45^{\circ} \mathrm{C}$, and decreased to (1.9, 3.1) $\mathrm{U} / \mathrm{ml}$ respectively at $80^{\circ} \mathrm{C}$, which may be attributed to the denaturation of the enzyme after incubation at high temperature due to structural and conformational changing of the protein molecule, this will influence the binding of enzyme and substrate [22]. The optimum temperature for isoamylase activity from Pseudomonas amylodermosa was $50^{\circ} \mathrm{C}$ [23].

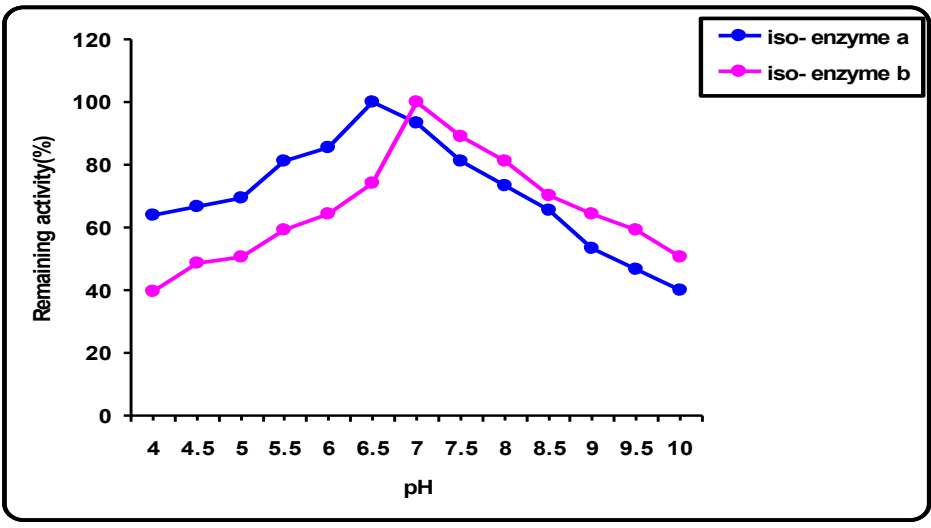

Figure (5): Effect of pH on amylase (iso-enzymes) stability purified from Pseudomonas sp.SPH4

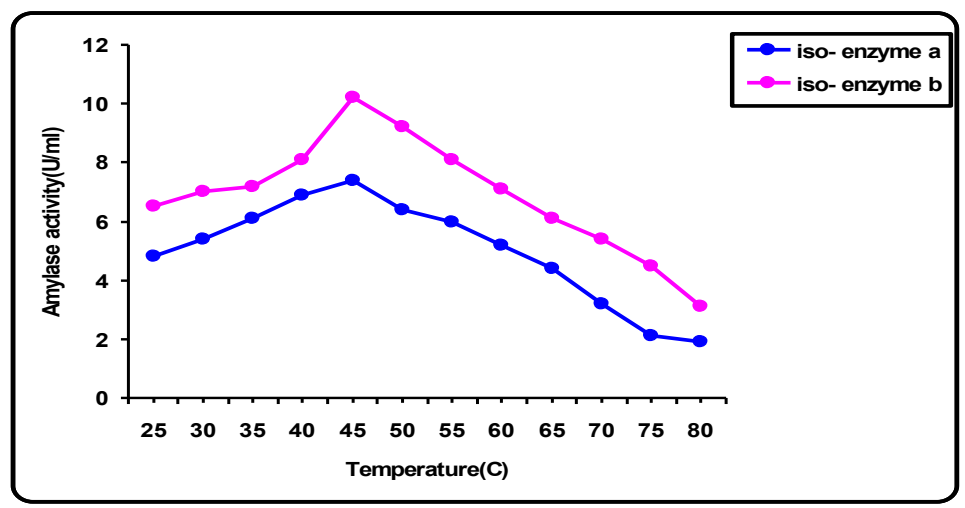

Figure (6): Effect of temperature on Pseudomonas sp.SPH4 amylase (iso-enzymes) activity

\section{Effect of temperature on amylase stability}

The stability of amylase iso-enzyme $\mathrm{a}$ and $\mathrm{b}$ from Pseudomonas sp. SPH4.was examined by enzyme incubation at various temperature $(30-80)^{\circ} \mathrm{C}$ for $15 \mathrm{~min}$. The results in Figure (7) revealed that the iso-enzyme are stable at $30-50^{\circ} \mathrm{C}$, the activity declined at higher temperature, although at $60^{\circ} \mathrm{C}$ about $60 \%$ of the activity remained. The enzyme was suppressed at $80^{\circ} \mathrm{C}$, about $20 \%$ of the activity remained. The activity of amylase (iso-enzyme a) was $7.5 \mathrm{U} / \mathrm{ml}$ and the activity of amylase (iso-enzyme b) was $11.1 \mathrm{U} / \mathrm{ml}$. The amylase produced by Bacillus sp. is stable at temperature over 60 ${ }^{\circ} \mathrm{C}$, and lost its activity at $95^{\circ} \mathrm{C}$ after $10 \mathrm{~min}$ [5]. 


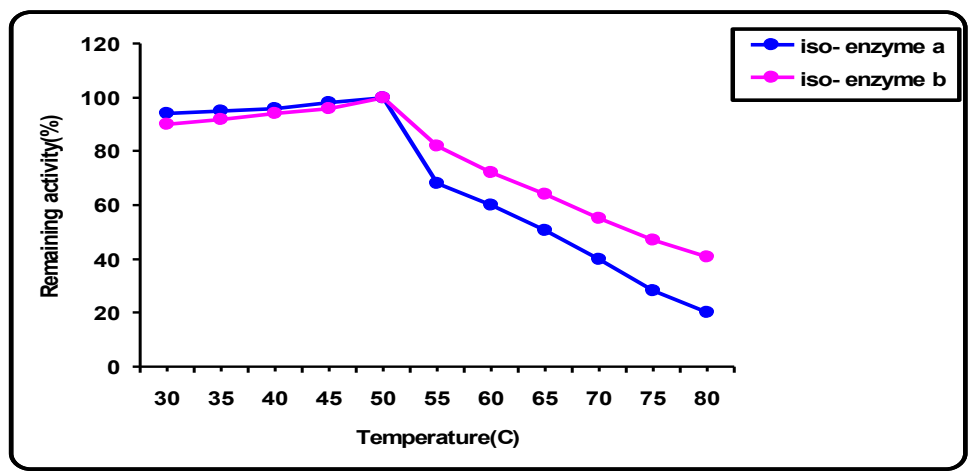

Figure (7): Effect of temperature on the purified Pseudomonas sp.SPH4

Amylase ( iso-enzymes) stability

\section{Effect of some chemical compounds on enzyme activity}

\section{Effect of metal ions on enzyme acyivity}

The results of amylase (iso-enzymes) treated with metal ions Table(2) showed that the amylase activity iso-enzymes $(\mathrm{a}, \mathrm{b})$ was decreased when treated with $(5,10) \mathrm{mM}$ of $\mathrm{HgCl} 2, \mathrm{AgCl}$ and $\mathrm{CuSO}$.The inhibition of amylase activity iso-enzymes $(\mathrm{a}, \mathrm{b})$ by $\mathrm{HgCl} 2, \mathrm{AgCl}$ and $\mathrm{CuSO} 4$ may indicated the presence of $\mathrm{SH}$ group in the active site of the enzyme leading to oxidize them by $\mathrm{HgCl}$, further more the presence of $\mathrm{HgCl}_{2}$, $\mathrm{AgCl}$ and $\mathrm{CuSO} 4$ in the substrate working solution may form a complexes with the enzyme which prevent it from binding to the substrate and form the product. The activity of amylase enzyme produced by Pseudomonas $s p$. enhanced by $\mathrm{Mg}^{+2}, \mathrm{Ca}^{+2}$ , $\mathrm{Rb}^{+}$, at $1 \mathrm{mM}$, while the activity was inhibited by $\mathrm{Ag}^{+}, \mathrm{Hg}^{+2}$, and $\mathrm{Cu}^{+2}$ at $1 \mathrm{Mm}$ [19].

Table (2): Effect of metal ions on purified Pseudomonas sp.SPH4 amylase iso-enzymes activity

\begin{tabular}{cccc}
\hline Metal salt & $\begin{array}{c}\text { Concentration } \\
(\mathrm{mM})\end{array}$ & \multicolumn{2}{c}{ Remaining activity \% } \\
& & & \\
& & iso-enzyme a & iso-enzyme b \\
Control & - & 100 & 100 \\
CuSO4 & 5 & 66.6 & 72.72 \\
& 10 & 53.3 & 64.54 \\
AgCl & 5 & 46.66 & 36.36 \\
& 10 & 28 & 28.18 \\
HgCl2 & 5 & 41.33 & 33.63 \\
& 10 & 25.33 & 19.09 \\
CaCl2 & 5 & 96 & 97.2 \\
& 10 & 101.3 & 101.8 \\
\hline
\end{tabular}

\section{Effect of reducing and chelating agents on enzyme activity}

The results in the Table (3) revealed the effect of reducing and chelating agents on amylase iso-enzymes a and $\mathrm{b}$ activity, the amylase (iso-enzymes $\mathrm{a}$ and $\mathrm{b}$ ) activity was not inhibited when it was incubated with $(2,5) \mathrm{Mm}$ of 2- mercaptoethanol, these results indicated the presence of $\mathrm{SH}$ group in or near the active site. The reducing compounds aid the SH group to be stable. The amylase produced by Bacillus $s p$. remained active when treated with reducing agent 2-mercaptoethanol at $1 \mathrm{mM}$. [5]. Pseudomonas sp.SPH4 amylase (iso-enzyme a and b) was inhibited by chelating agent (EDTA) at $(2,5) \mathrm{mM}$, these results indicated that these iso-enzymes refered to 
metalloamylases on which the activity of enzyme is dependent on the some kinds of ions. Additional chelating agents to the reaction medium it forms complexes with the ions in the active site which cause inhibition of enzyme activity. The amylase produced by Bacillus stearothermophilus was inhibited by chelating agent (EDTA) at $10 \mathrm{mM}$ [19]. The amylase iso-enzyme $\mathrm{a}$ and $\mathrm{b}$ did not affected by the present of PMSF in the reaction mixture at $(1,5) \mathrm{mM}$ indicated that these iso-enzymes are not belong to serine amylases. The activity of amylase produced by Bacillus sp. did not affected in the presence of $10 \mathrm{mM}$ of PMSF [5].

Table (3): Effect of reducing and chelating agents on Pseudomonas sp.SPH4 amylase (isoenzymes) activity.

\begin{tabular}{cccc}
\hline Compound & $\begin{array}{c}\text { Concentration } \\
(\mathbf{m M})\end{array}$ & \multicolumn{2}{c}{ Remaining activity\% } \\
& & & \\
& & & \\
iso-enzyme a & iso-enzyme b \\
Control & - & 100 & 100 \\
EDTA & 2 & 45.33 & 43.63 \\
& 5 & 28 & 28.18 \\
2-mercaptoethanol & 2 & 92 & 92.72 \\
& 5 & 85.3 & 89.09 \\
PMSF & 1 & 93.33 & 90.90 \\
& 5 & 90.66 & 87.27 \\
\hline
\end{tabular}

\section{References}

1. Reddy, N.S.; Nimmagadda, A. and Rao, K. R. S. S. (2003). An overview of the microbial $\alpha$ - amylase family. Afri. J. Biotechnol. 2(12): 645-648.

2. Cornelis, P. (1987).Microbial amylase. Microbiol. Sci. 4(11): 342 - 343.

3. Pandey, A.; Nigma, P.; Soccal, C.R.; Soccal, V.T.; Singh, D. and Mohan, R. (2000). Advances in microbial amylase. Biotechnol. Appl. Biochem. 31: 135- 152.

4. Shaw, J. F.; Lin, F. P. S. C. and Chen, H. C. (1995). Purification and properties of a cellular $\alpha$-amylase from Thermus sp. Bot. Bull. Acad. Sin. 36: $195-200$.

5. Lin, L. L.; Hsu, W. H. and Chu, W. S. (1998). Production and properties of a raw starch- degrading amylase from the thermophilic and alkaliphilic Bacillus sp. Ts- 23. Biotechnol. Appl.Biochem. 28: 61-68.

6. Fujita, M.; Torigoe, K.; Nakada, T.; Tsusaki, K.; Kubota, M.; Sakai, S.and Tsujisaka, Y. (1989). Cloning and nucleotide sequence of the gene (amy $P$ ) for maltotetraoseforming amylase from Pseudomonas stutzeri MO-19.J. Bacteriol. 171(3): 1333-1339.

7. Nielsen, J. E.; Beier, L.; Otzen, D.; Borehert, T. V.; Frantzen, H. B; Andersen , K. M. and Svendsen, A. (1999). Electrostatics in the active site of $\alpha$-amylase. Eur. J. Biochem. 264: 816 - 824 .

8. Kiran, Ö.; Com lekcioglu, U. and Akrian. B. (2005). Effect of carbon sources and various chemicals on the production of a novel amylase from a thermophilic Bacillus sp. K-12. Turk. J. Biol. 29: 99 - 103.

9. Srivastava, R. A. K. (1987). Purification and chemical characterization of thermostable amylase produced by Bacillus streaothermophilus. Enzyme. Microbiol. Technol. 9: 749 - 754.

10. Ali, M. Hala. Determination of the optimum conditions for the production of 
Amylase from local isolate Pseudomonas sp. SPH4 proceeding of $3^{\text {rd }}$ scientific conference Of the College of Science, University of Baghdad 24 to 26 March 2009.(In Arabic).

11. Toye Ekunsaumi (2001). Uw-Washington country. Laboratory production and assay of amylase by Fungi and Bacteria. (Internet).

12. Lin, L. L.; Hsu, W. H. and Chu, W. S. (1997). A gene encoding for $\alpha$-amylase from thermophilhc Bacillus sp.strainTs-23and it s expression in Escherichia coli. J. Appl. Microbiol. 82: 325- 334.

13. Bradford, M. (1976). A rapid and sensitive method for the quantitation of microgram quantities of protein utilizing the principle of protein-dye binding. Anal. Biochem. 72: $248-254$.

14. Aiyer, P. V. D. (2004). Effect of $\mathrm{C}: \mathrm{N}$ ratio on alpha-amylase production by Bacillus licheniforms spT 27. African. J. Biotechnol. 3(10): 519 - 522.

15. Whitaker, J. R. and Bernard, R. A. (1972). Experiment for Introduction to Enzymology. The Wiber Press Davis. Inc.New York, USA. Segel, I. H. (1976). Biochemical Calculations, 2nd edition, John and Sons. Inc. New York.

16. Englard, S., and Seifter, S. (1990).Precipitation techniques In: Methods in Enzymology (ed.Murray, E. D. and Dentscher, P.).182: 425-441.

17. Volesky, B., and Loung, L. (1985). Micrbial enzymes production, purification and isolate (CRC) (Critical Review in Biotechnology. 2:119.

18. Srivastava, R. A. K. (1987). Purification and chemical characterization of thermostable amylase produced by Bacillus streaothermophilus. Enzyme. Microbiol. Technol. 9: $749-754$.

19. Neilsen, J.E.; Borchert,T.V.; and Vriend, G.(2001) . The determinants of $\alpha$-amylase pH activity profiles. Protein.Engineer.14 (7): 505-512.

20. Spencer-Martin, (1982) .Extracellular isoamylase produced by the yeast Lipomyces kononenkae . Eur.J.Appl.Microbiol.44 (60):1253-1257.

21. Wang, H. (1999). Biochemical characteristics of cholesroloxidase immobilized in a polyaniline film. Biochem. Biophys. Res. Commun. 56:22-30.

22. Katsuya, Y., Mezaki,Y., Kubota, M. and Matsuura, Y.(1998).Three-dimensional structure of Pseudomonas isoamylase at 2.2A ${ }^{\circ}$ resolution.J. Mol. Biol. 281:885-897. 